
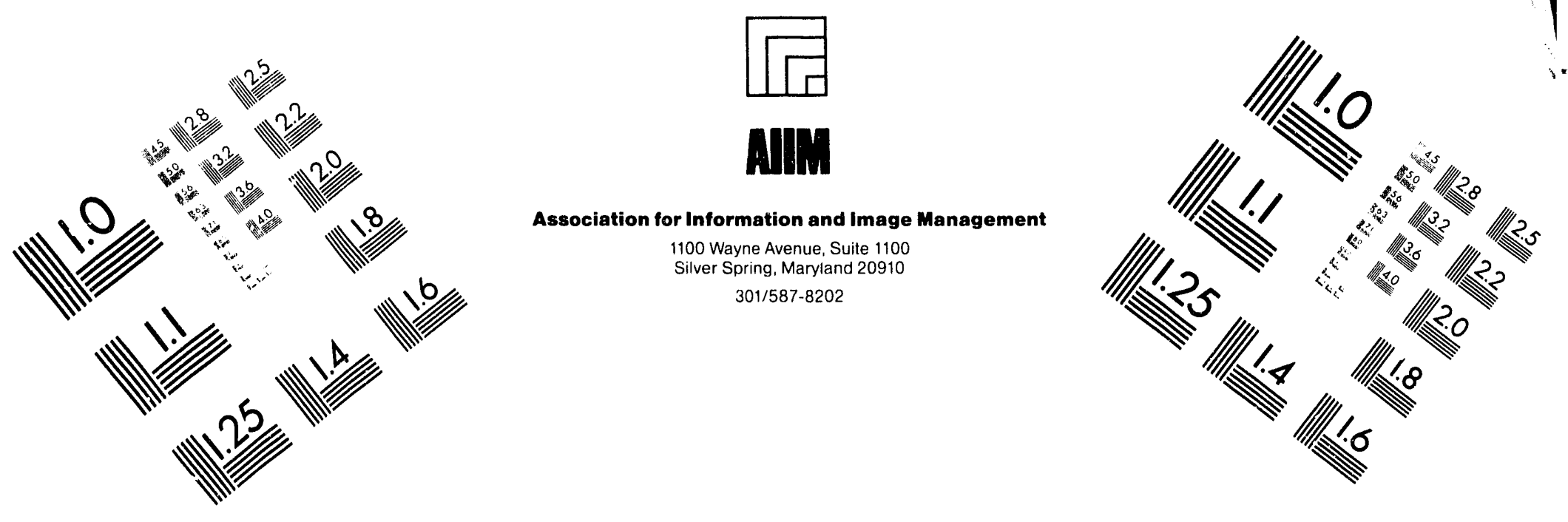

\title{
Centimeter
}

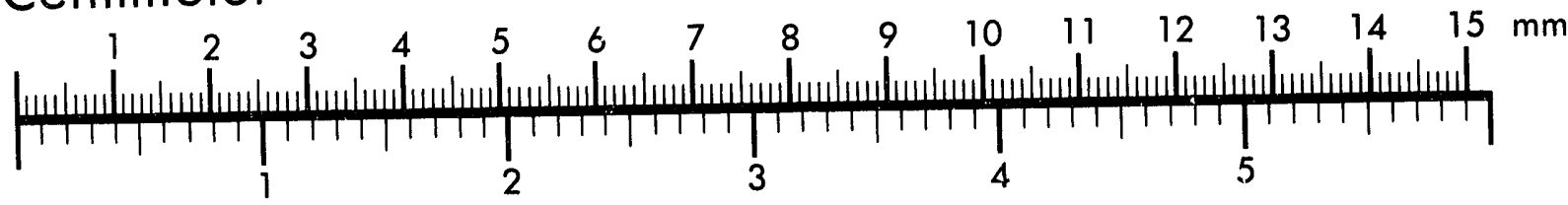
Inches
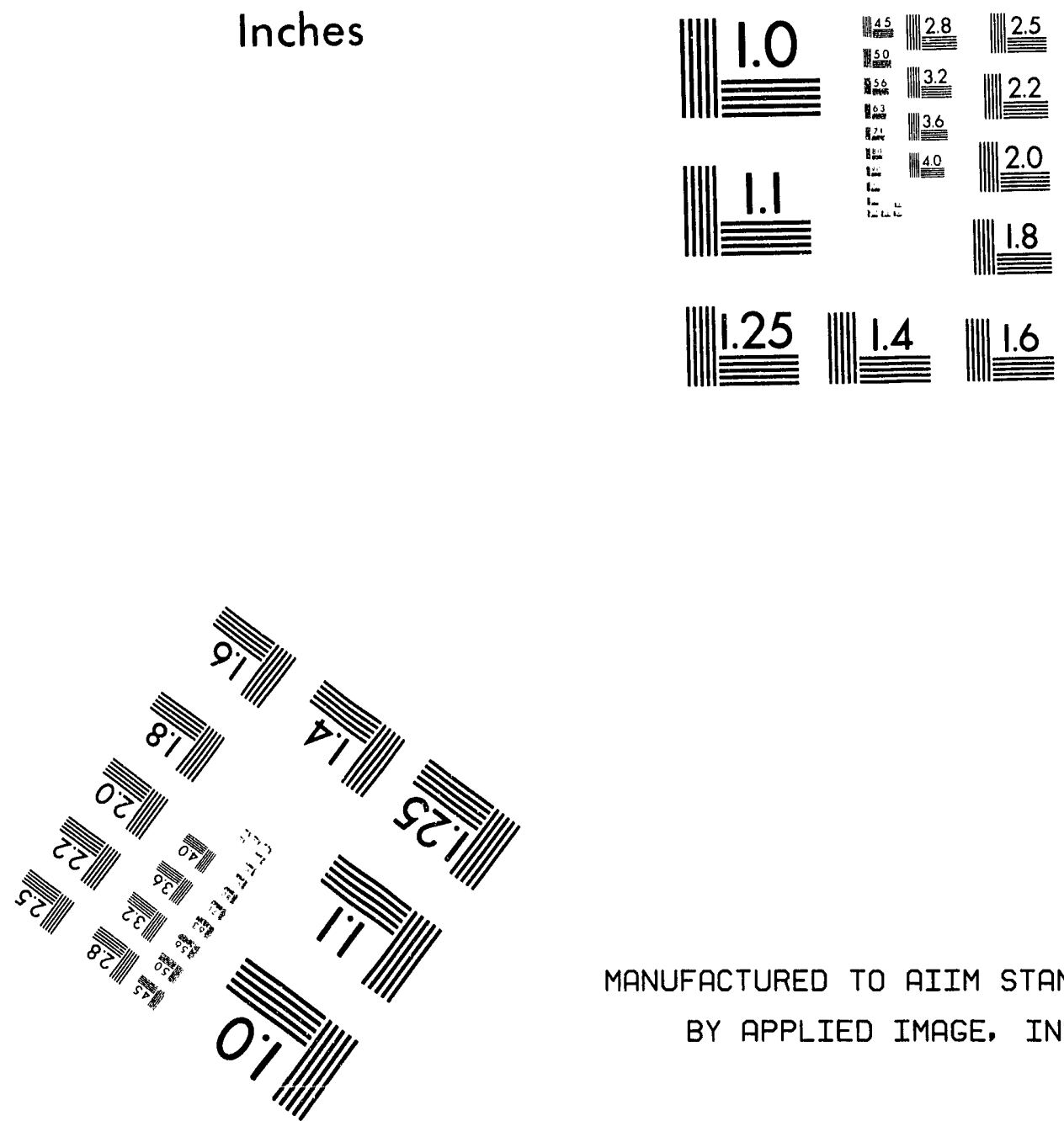

MANUFACTURED TO AIIM STANDARDS

BY APPLIED IMAGE, INC.

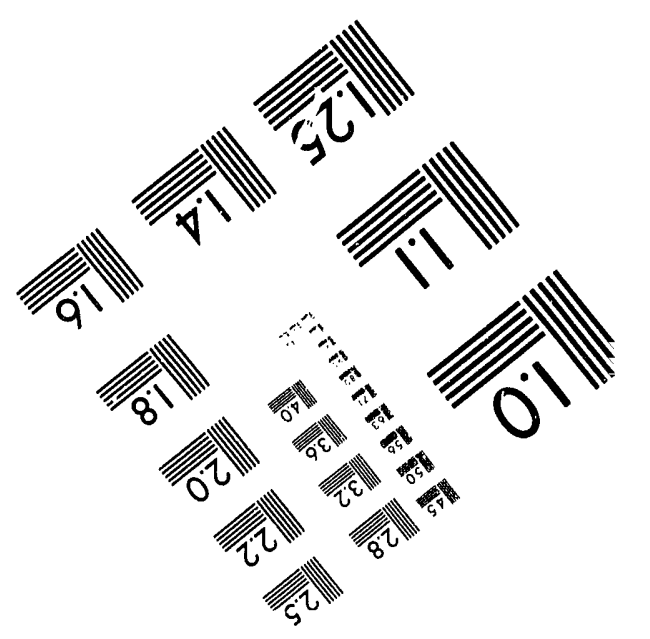



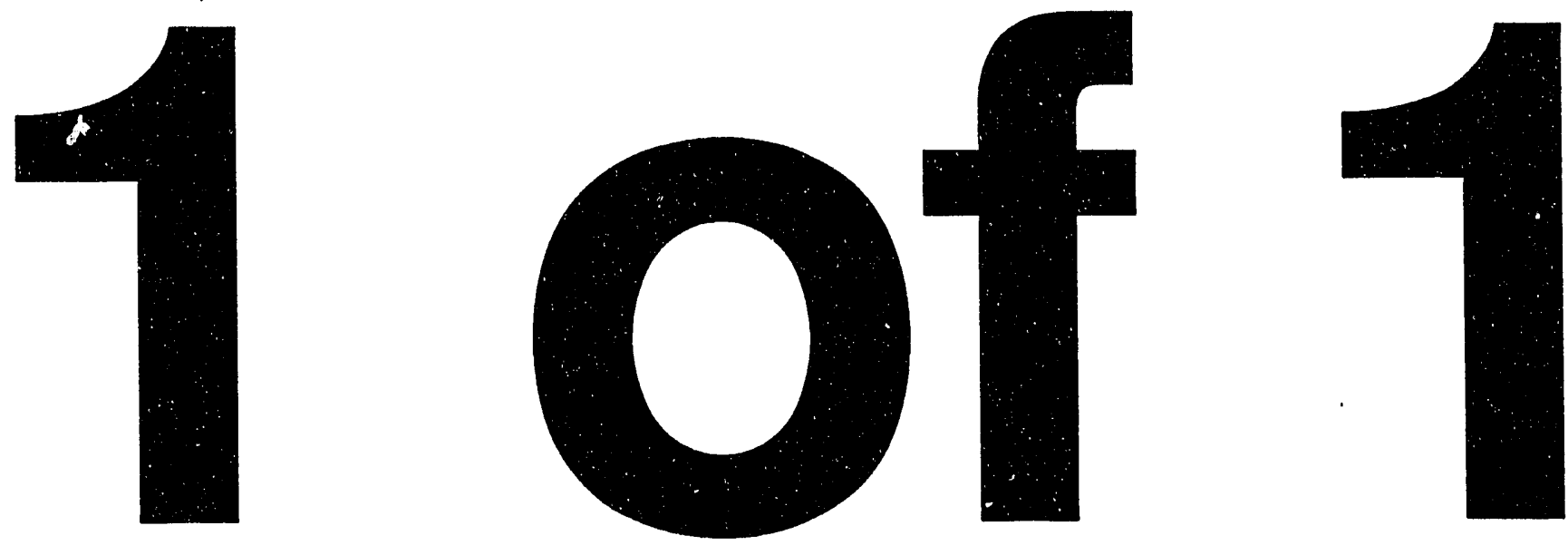


\section{MATERIAL HANDLING SYSTEMS FOR USE IN GLOVEBOX LINES - A SURVEY OF DEPARTMENT OF ENERGY FACILITY EXPERIENCE (U)}

by G. D. Teese

Westinghouse Savannah River Company

Savannah River Site

Aiken, South Carolina 29808

Other Authors:

W. J. Randall

(WSRC)

This paper was prepared in connection with work done under Contract No. DE-AC09-89SR18035 with the U. S. Department of Energy. By acceptance of this paper, the publisher and/or recipient acknowledges the U.S. Government's right to retain a nonexclusive, royalty-free license in and to any copyright covering this paper, along with the right to reproduce and to authorize others to reproduce all or part of the copyrighted paper. 
MATERIAL HANDIING SYSTEMS FOR USE IN GLOVEBOX LINES A SURVEY OF DEPARTMENT OF ENERGY FACIIITY EXPERIENCE (U)

G. D. Teese

W. J. Randall

Westinghouse Savamah River Company

Savannah River Site

Aiken, SC 29808

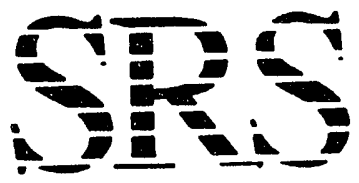




\title{
DISCLAIMER
}

\begin{abstract}
This report was prepared by Westinghouse Savannah River Company (WSRC) for the United States Department of Energy under Contract No. DE-ACO989 SR18035 and is an account of work performed under that contract. Neither the United States Department of Energy, nor WSRC, nor any of their employees makes any warranty, expressed or implied, or assumes any legal liability or responsibility for the accuracy, completeness, or usefulness, of any information, apparatus, or product or process disclosed herein or represents that its use will not infringe privately owned rights. Reference herein to any specific commercial product, process, or service by trademark, name, manufacturer, or otherwise does not necessarily constitute or imply endorsement, recommendation, or favoring of same by WSRC or by the United States Government or any agency thereof. The views and opinions of the authors expressed herein do not necessarily state or reflect those of the United States Government or any agency thereof.
\end{abstract}


MATERIAL HANDLING SYSTEMS FOR USE IN GLOVEBOX LINES -

A SURVEY OF DEPARTMENT OF ENERGY FACILITY EXPERIENCE (U)

G. D. Teese

W. J. Randall

November 1992

Westingbouse Savamah River Company

Savannah River Site

Aiken, SC 29008

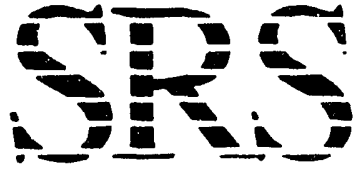


Title: Material Handling Systems For Use In Glovebox Lines A Survey of Department of Energy Facility Experience

APPROVALS
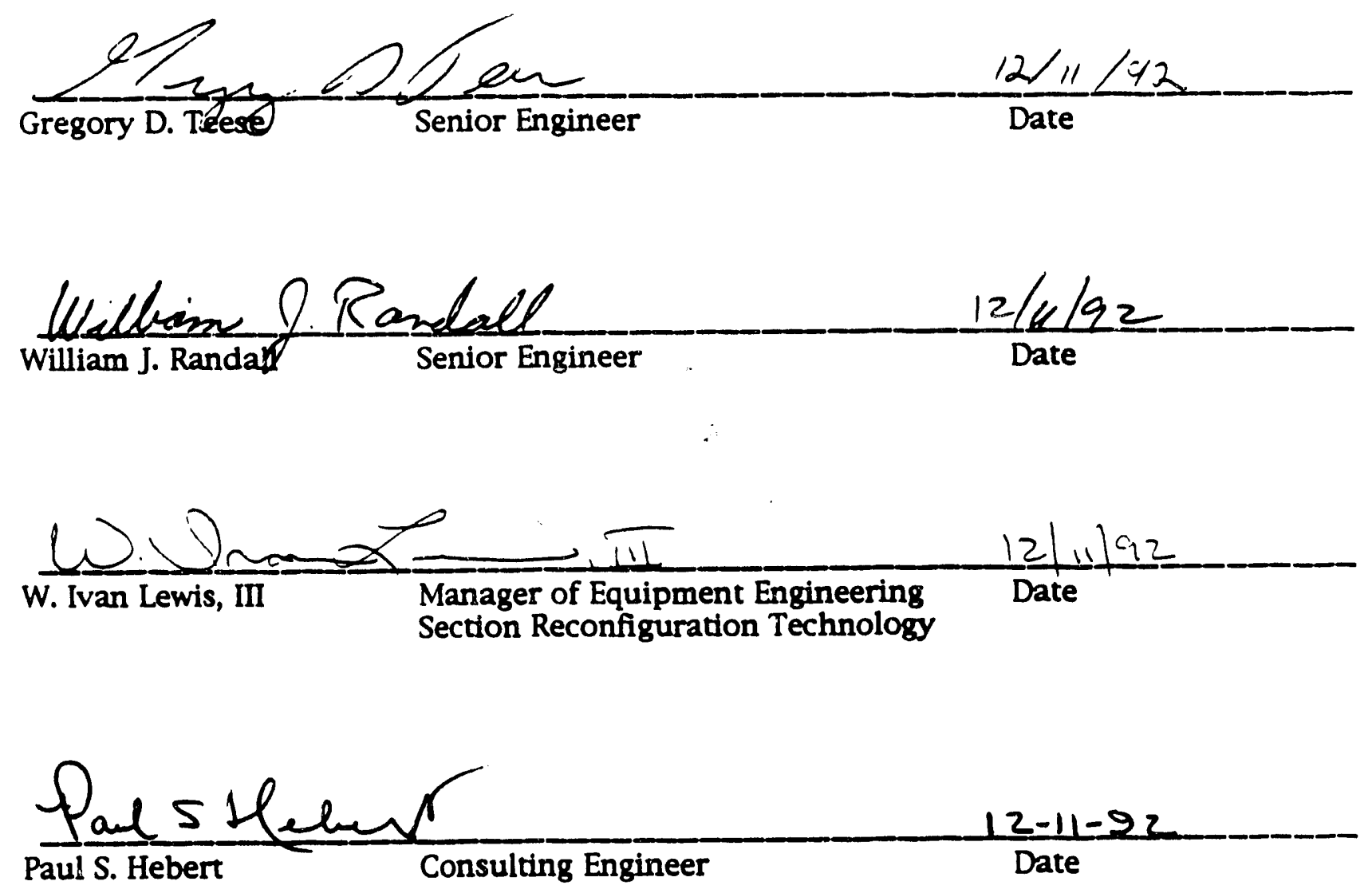


\section{Table of Contents}

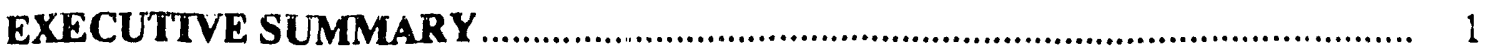

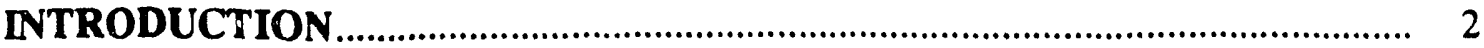

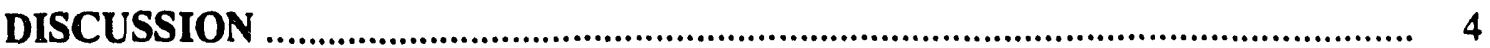

Material Handling and Automation .................................................................. 4

Material Handling and Automation - An Industrial Perspective............................... 4

Material Handling and Automation - A Weapons Complex Perspective ................ 5

Automated Material Handling for Gloveboxes .................................................... 6

Existing Component Transport ................................................................................. 7

Alternative Technologies .............................................................................. 8

Conveyor Systems............................................................................................. 9

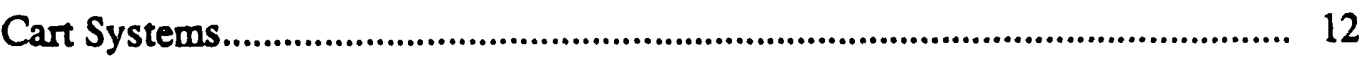

Linear Motor Systems .................................................................................... 18

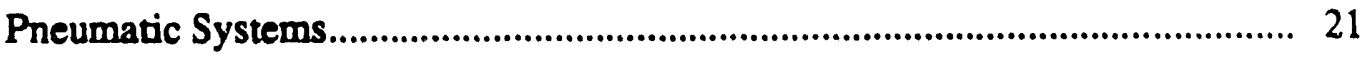

CONCLUSION

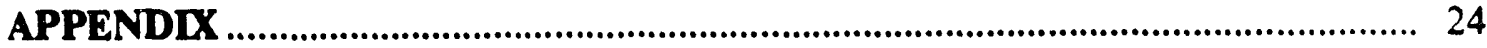

REFERENCES 


\section{EXECUTIVE SUMMARY}

The Nuclear Weapons Complex Reconfiguration Study has recommended that a new manufacturing facility be constructed to replace the Rocky Flats Plant. In the new facility, use of an automated material handling system for movement of components would reduce both the cost and radiation exposure associated with production and maintenance operations. Contamination control would be improved between process steps through the use of airlocks and portals. Part damage associated with improper transport would be reduced, and accountability would be increased. In-process workpieces could be stored in a secure vault, awaiting a request for parts at a production station. However, all of these desirable features rely on the proper implementation of an automated material handling system.

The Department of Energy Weapons Production Complex has experience with a variety of methods for transporting discrete parts in glovebox lines. The authors visited several sites to evaluate the existing technologies for their suitability for the application of plutonium manufacturing. Technologies reviewed were linear motors, belt conveyors, roller conveyors, accumulating roller conveyors, pneumatic transport, and cart systems. The sites visited were The Idaho National Engineering Laboratory, the Hanford Site, and the Rocky Flats Plant.

Linear motors appear to be the most promising technology observed for the movement of discrete parts, and further investigation is recommended. 


\section{INTRODUCTION}

The Nuclear Weapons Complex Reconfiguration Study has recommended that a new manufacturing facility be constructed to replace the Rocky Flats Plant. The Savannah River Technology Center (SRTC) has been interacting with the Department of Energy (DOE) national laboratories, weapons complex production sites, and commercial vendors on technology development needs for the Plutonium Working Group of the Technology Assessment and Selection Panel (TASP). One area identified for improvement is the material handling systems employed in glovebox lines. In the new facility, use of an automated material handling system could reduce both the cost and radiation exposure associated with production and maintenance operations. Through proper implementation, contamination control would be improved, part damage would be reduced, and accountability would be increased. The primary area of concern, and the focus of this report, is the transport of discrete parts between processing steps (component transport). A secondary concern is the movement of small samples from the processing line to the analytical laboratory (sample transport).

The existing pit manufacturing process at Rocky Flats uses an overhead chain conveyor to transport open-topped product carriers between process steps. The system is physically long, with one chain servicing many workstations. The lubrication on the chain tends to accumulate contamination, and provides a mechanism for spread of contamination between gloveboxes. The ability to transport many components simultaneously was an advantage in prior years. Current forecasts, however, favor systems that are flexible, with lower unit capacity.

A modern component transport system must satisfy a broad range of criteria. In addition to transporting the material, the component transport system must meet a variety of criteria unique to the weapon production complex. The system must be easy to maintain or repair, with minimal radiation exposure to maintenance personnel. The system should ensure criticality spacing is maintained, and allow a method for real-time accountability. Transport of materials in closed containers is desired for cleanliness and contamination control purposes. The system should provide for airlocks or portals, to minimize cross contamination between process steps. Finally, the 
system should be easily adapted for interfacing with human operators or automatic processing equipment, including robots.

The DOE Weapons Complex has experience with alternative methods of glovebox transport. The authors visited several sites to evaluate the other technologies for their suitability for plutonium manufacturing. This report is a summary of the technologies observed, the lessons learned, and worthwhile areas for further development. 


\section{DISCUSSION}

Material Handling and Automation

The use of automated material handling reduces the amount of labor input to a product. The labor savings is frequently used to justify the capital investment in the material handling systems. However, factors other than hardware cost can also influence the choice of material handling methods. Different industries will place differing values on the non-capital costs associated with automation. For example, reduced radiation exposure may be more important to the Weapons Complex, and elimination of lag storage may be more important to industry. Understanding the role of material handling in an enterprise will help define the appropriate hardware to accomplish that role.

\section{Material Handling and Automation - An Industrial Perspective}

In the industrial sector, it is generally accepted that material handling does not add value to parts being produced. The handling, transporting, storing, and controlling the materials does not contribute to its usefulness, quality, or salability. These nonproductive efforts only serve to increase costs. Studies of materials handling place these costs from $20 \%$ to $40 \% 1,2,3,4$. In addition, improper material handling can increase costs through damaged goods, lost or mis-routed material, material retained beyond its useful shelf life, and production down-time associated with maintenance and repair of the material handling equipment. 4

The potential savings associated with the reduction of material handling costs has led to new developments in material handling and automation. Industrial material handling and automation technology has evolved from mass production and large lot sizes towards a "lot size of one." Dedicated process lines of "hard automation" are used to produce part quantities in the hundreds of thousands. The automation of smaller lot sizes was made possible through the development of "flexible automation" such as reprogrammable robots. Flexible automation systems, once programmed and supplied with appropriate tooling and fixtures, could economically produce lots in the thousands or less. "Design for Manufacturability" has identified methods of altering the product design to exploit the capabilities of flexible automation. "Group Technology" takes 
advantage of the common features of "families" of related products. The "families" can be produced on the same production line by" implementing software control over product options. The results is cost-effective automation of low batch sizes for industry.

\section{Material Handling and Automation - A Weapons Complex Perspective}

For the DOE Weapons Complex, the development of material handling took a different path. Radioactive materials required remote handling to mitigate personnel hazards. Innovations in radioactive material handling included master-slave manipulators, servomanipulators, and remote controlled cranes. Alpha-emitting materials such as plutonium did not require such elaborate techniques, and were manually handled in gloveboxes.

The success of flexible automation in industry led to its application in the Weapons Complex. In recent years, the Kansas City, Mound, and Pinellas facilities have all had limited success with robotic installations in non-nuclear portions of their processes. 5 Greater success may be achievable if the cost effectiveness could be increased. Cost effectiveness has not been achieved due to the low lot size in the Complex. Product design is driven by optimization of performance, not ease of manufacture. Thus, many of the techniques employed by industry to increase the cost effectiveness for small lot sizes are not used in the Weapons Complex. For example, "Design for Manufacturability" has not been applied to the products of the Weapons Complex and "families" of piits do not exist. Custom programming of flexible automation would be required to accommodate each unrelated part. Custom fixturing would also be required. From an electromechanical standpoint, industrial automation is currently capable of accomplishing many production operations. The cost associated with utilizing this capability, however, has been excessive. Research is currently underway at DOE's National Laboratories to reduce the costs of programming and fixturing. 6

The sites which handle radioactive materials, particularly the Rocky Flats site, have not had even the limited success that the non-nuclear sites have had. In the glovebox environments associated with plutonium processing, industrial automation has not proven to be electromechanically acceptable. The result is that frequent mechanical breakdowns necessitate high maintenance. Attempts to 
automate production to reduce operator exposure merely resulted in transferring the exposire to the maintenance personnel. The Plutonium Processing Autcmation Review Team (PPART) expressed the following:

Two issues became apparent io PPART in the course of this study. The first issue involves the necessity of achieving a highly reliable, maintenance-free system in a glovebox environment. Not only is it difficult to maintain any system contained within a glovebox, but the radiation dose received by the maintenance worker can be prohibitive. Where niaintenance cannot be avoided or where failures may be aisticipated, it is essential to design systems which are very easy to service.

The second issue is related to the additional difficulties of working in a glovebox environment. Not only is access limited, but additional environmental factors such as alpha radiation, dusting, and ultra-dry inert atmosphere or corrosive atmospheres adversely affect equipment operation and reliability. Since even straight-forward robotic applications require careful analysis and complete engineering and testing to be successful, it is essential that a major commitment be made before undertaking a robotic or automation application in plutonium processing. Unless such a commitment can be made in terms of time and resources, the automation should not be attempted. 5

\section{Automated Material Handling for Gloveboxes}

Based on the above, it is clear that an effective, well developed and well engineered material handling system can reduce the cost of operating a new plutonium manufacturing facility. However, inadequate development or inadequate definition of the system requirements will be a source of problems for years to come. For this इeason, the Plutonium Working Group of the Technology Assessment and Selection Panel has identified improved component transport as a highly desired technology.

An automated material handling system, properly implemented, would be able to reduce the cost of building and operating the new 
facility. Radiation doses to both maintenance and operating personnel would be decreased, and contamination control could be augmented through the use of airlocks and portals. Part damage associated with improper transport wc'ld be reduced, and accountability would be increased. In-process workpieces could be stored in a secure vault, awaiting a request for parts at a production station. However, all of these benefits rely on proper implementation of automated material handling.

The existing material handling of plutonium at Rocky Flats was examined as a baseline technology. Alternate technologies being used within the Weapons Complex were then explored to define those technologies with limited development needs. The applicability of the observed technologies to the needs of Complex 21 was then evaluated.

Industry will minimize risk in automating material handling "by automating the common denominator (container, pallet, tote box) instead of the product." 4 For the specific application of production of weapon pits, two types of product containers are envisioned. One container would be used for "work-in-process," that would include raw materials, semi-finished parts, sub-assemblies, and completed pits. The second container would be used to transport samples for laboratory analysis. The primary focus of this study was the movement of "work-in-process," which is referred to as "component transport." However, sample transport systems were noted, and are presented for reference for future work.

\section{Existing Component Transport}

The existing pit manufacturing process at Rocky Flats uses an overhead chain conveyor to transport open-topped product carriers between process steps. The system addressed the requirements that existed when it was installed. It was able to transport many components simultaneously, and move them sequentially through the process. The system did automate the carrier, not the product, and the open-topped product carrier was used to move supplies and other materials, as well as products, on occasion.

However, the chain conveyor travels throughout the entire process. While this would not present problems in many industries, it does in 
pit manufacturing. The water and acid fumes of the aqueous processing area permeate the pyrochemical area, which requires a dry, inert atmosphere. This leads to pyrochemical operating difficulty and corrosion of non-stainless steel components.

Changes in security regulations have also impacted the existing process. Storage of in-process components on the conveyor is no longer acceptable, and they must be returned to vault storagge. Consequently a part may make several visits to the vault before it is completed. The fixed routing of the chain conveyor dictates that the part will not go directly from the processing station to the vault, but will first travel past other processing stations before finally reaching the vault. Much of the material handling is therefore non-productive transit from vault to process and back. The ability to transport a large number of components had been an advantage when the facility was at full production. Current forecasts, however, favor systems that are flexible, with lower unit capacity. The flexible routing would prevent long wait times associated with products being routed past other processing stations while in transit to the vault for storage.

Operator exposure has increased both from non-productive wait time while parts are retrieved from vault storage, and from contamination being transported in the chain lubricant. In addition, operators may also have increased exposure while waiting for the conveyor to become available for their use.

\section{Alternative Technologies}

Radioactive materials are automatically transported at other DOE facilities by a variety of technologies. Many of the systems examined were developed and installed after the Rocky Flats chain conveyor. Advances in industrial automation and evolving DOE Order requirements have impacted the choice of material handling hardware for glovebox applications.

Material handling systems for component transport were observed at the Idaho National Engineering Laboratory, the Hanford site, the Savannah River Site, and newer facilities at Rocky Flats. These sites used a variety of technologies including belt conveyors, roller conveyors, accumulating roller conveyors, self-propelled battery 
powered carts on a track, manually operated, rope-pulled carts, and linear motor systems.

A number of the facilities visited were intended for radioactive service, however they had not yet "gone hot." Therefore, the maintainability of these systems under the working conditions imposed by gloved access is still not completely known.

Although all sites visited also had material handling systems outside of containment systems (for non-radioactive items), these were not considered. This study was intended to evaluate only those systems specifically designed for use in radioactive material service.

\section{Conveyor Systems}

Conveyors are used throughout industry for moving items along a fixed path. Its motion may be continuous or intermittent, with motive force supplied externally, or by gravity. For purposes of this report, conveyors will be considered to be those fixed path transport systems characterized by a frame with side pieces, and a transport surface contained within the frame.

Roller conveyors have cylindrical members (rollers) which span the distance between the frame sides, and are perpendicular to the direction of travel. Powered (or "live") roller conveyors have external power supplied to rotate the rollers, and move the items on the conveyor. Gravity roller conveyors depend upon the conveyor slope or manual force to impart motion to the items. A common variation on this type of conveyor is the wheel conveyor, where the rollers are replaced with an axle with multiple wheels along its length.

Live roller conveyors can be made "accumulating." That is, items may be restricted from movement by restraining them, however the rollers continue to move beneath the items. Gravity conveyors are naturally accumulating. One example of an accumulating conveyor, the Slip-Torque Conveyor by Shuttleworth, is shown in Figure 1. The motion of the roller is transmitted to the item by a number of small wheels, all of which are concentric to the roller. There is a friction coupling between the small concentric wheels and the powered roller, thus allowing the item to be held stationary, yet allow the roller to rotate. 
The Shuttleworth Slip-Torque ${ }^{\circledR}$ Conveyor was observed in the Secure Automated Fabrication (SAF) line at the Fuels and Materials Examination Facility (FMEF) at Hanford. The SAF line, which was designed to produce mixed-oxide reactor fuel, along with the rest of the FMEF has not yet "gone hot" due to the suspension of the US Breeder Reactor program. The SAF line was designed for automated and remote operation, with contact maintenance. 7 The handling of radioactive oxides was performed in an enclosed system similar to a glovebox line. The accumulating roller conveyor was required as part of the fuel fabrication process. Discussions with knowledgeable personnel at Hanford did reveal, however, that the anticipated maintenance on the conveyor made it less than ideal for a glovebox environment.

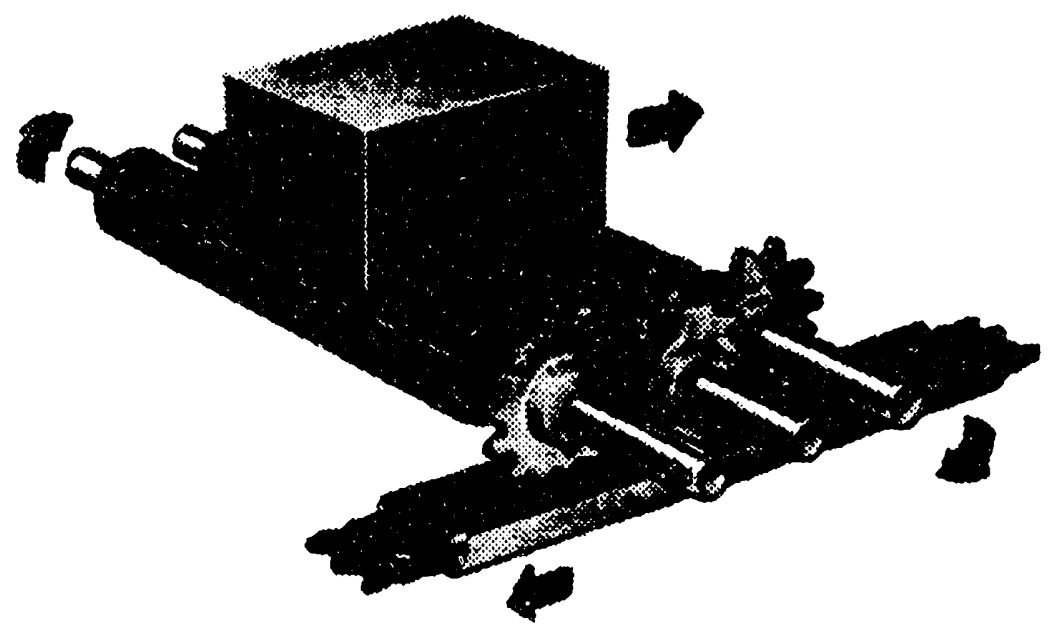

Figure 1

Accumulating Roller Conveyor

(Shuttleworth Slip-Torque ${ }^{\circledR}$ Conveyor)

The maintenance concerns centered around the large number of small parts which comprised the system. Figure 1, above, shows the drive chain, spur gears, rollers, and wheels which are all necessary for the operation of the system. It was the opinion of Hanford personnel that this system would be difficult to maintain through gloved entry into the SAF line. The authors concur with this opinion.

Conventional, non-accumulating, roller conveyors were also used for selected portions of the SAF line process. Although they were 
considerably less complex than the Shuttleworth system, maintenance was still a concern. Maintainability in glovebox environment is quite difficult, and should be factored in to equipment design.

Belt conveyors differ from roller conveyors in that a continuous loop of belting is installed between the side frames of the conveyor. The belt may be supported on rollers or wheels, but it is actually the belt which transmits motion to the item being moved. Belt conveyors are widely used in industry. When items are of varying sizes, and may cock or jam between rollers, belt conveyors are frequently employed. They are also popular when moving granular items unsuited for roller conveyor transport.

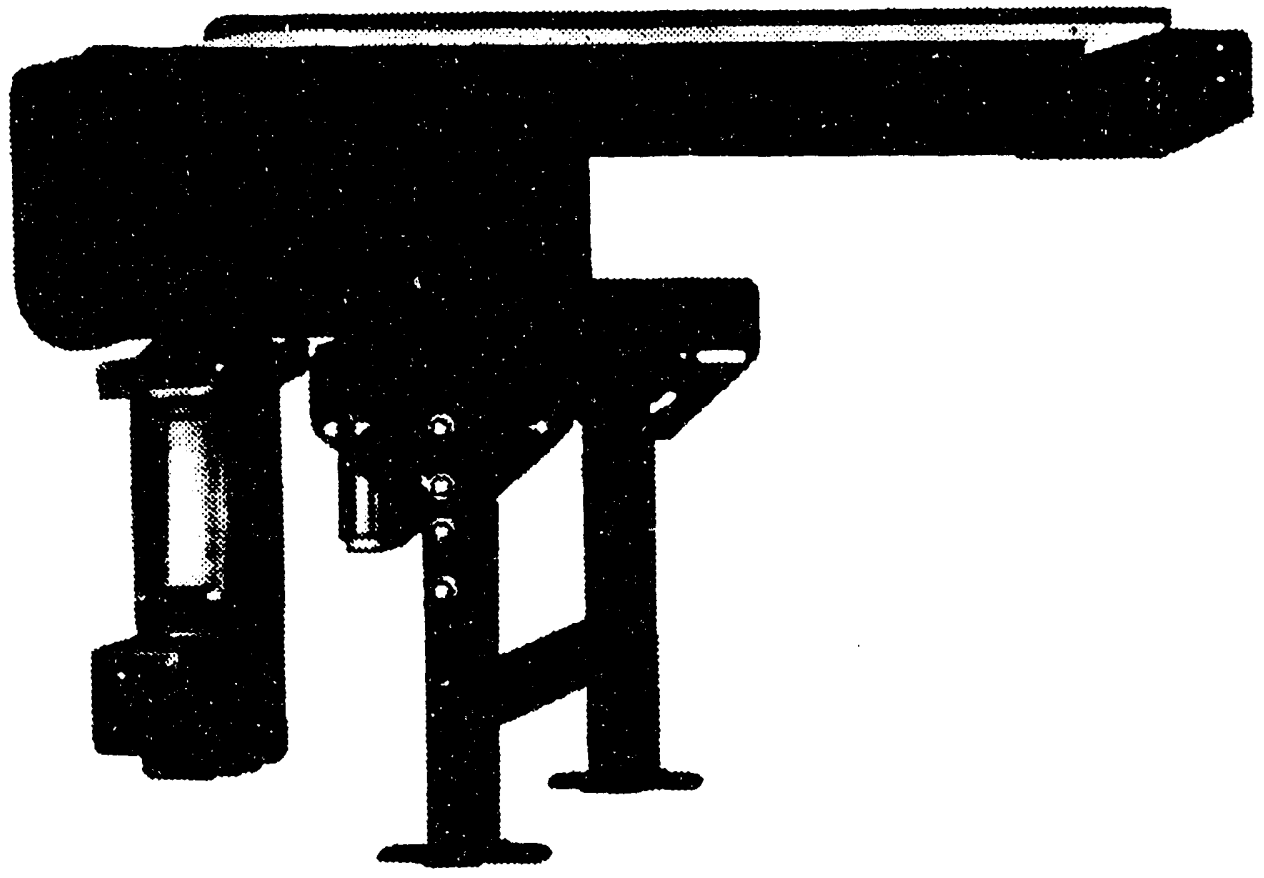

Figure 2

Section of Dorner Conveyor, With Motor and Frame

Some small belt conveyors by Dorner were also used in certain glovebox operations of the SAF line. A typical section of a Dorner belt conveyor is shown in Figure 2. Belts of either stainless steel mesh or rad-tolerant polymers were used, depending upon the product being moved. Replacement of failed belts would typically involve contact maintenance, however Dorner has considered belt replacement in the design of their conveyors, and claims easy belt 
replacement as a feature of their product. The relatively simple construction of the corveyor section can be seen in Figure 3. Unfortunately, no data on actual service life and replacement time for radioactive use were available.

In summary, a number of different conveyor systems were observed at the FMEF, however, none had actually been used in glovebox service. The maintainability of a conveyor system would be severely limited by the glovebox environment. The system observed which offered the most promise for maintainability was the belt conveyor by Dorner, which features speedy belt replacement.

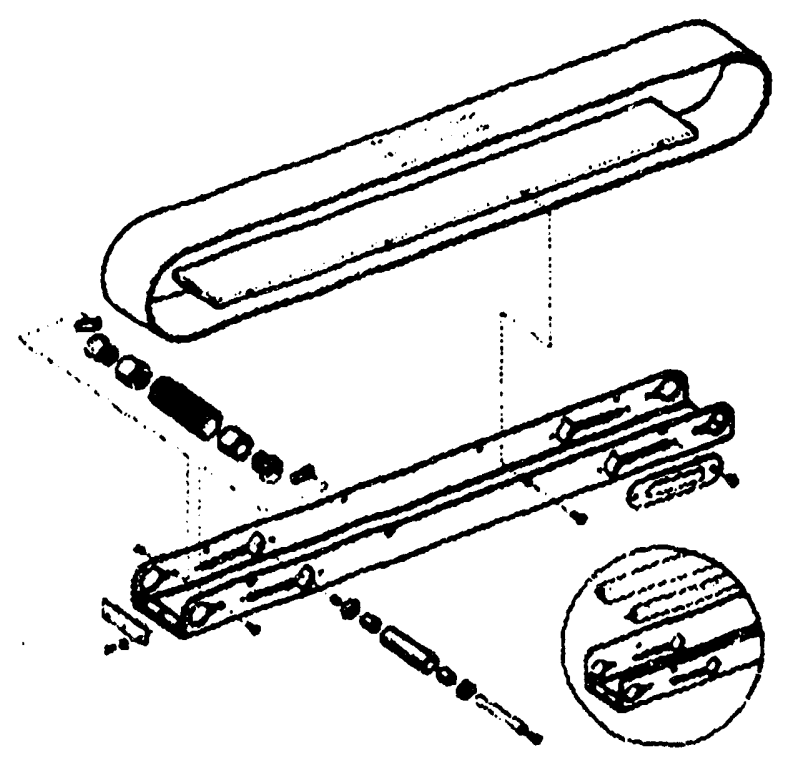

Figure 3

Assembly Sketch of a Dorner Conveyor

\section{Cart Systems}

An alternative to conveyors is a cart-based system. Cart systems, like conveyors, are fixed path systems. Items are placed on a cart, which is then transpcrted to the next destination. Movement of the cart can be accomplisiled in a variety of ways, including having the cart actually be the secondary of a linear motor. Due to the uniqueness of linear motor systems, they will be discussed separately. 
The most simple cart system was observed at Savannah River. The cart was positioned manually by operators pulling on the rope attached to the cart. Although this system may be well suited for manual operations, it is not appropriate for an automated system.

For short distances, lead screws are frequently employed. The resulting linear stage can be positioned quite accurately. Lead screws continue to be used successfully for precision motion of an item on a machine or in a workstation. However, lead screw systems are not practical for the main material handling method of a fabrication line, due to their limited length.

Industry has used a concept similar to the lead screw for a cart based material handling system. The Cartrac ${ }^{\circledR}$ and Mini-Cartrac ${ }^{\circledR}$ systems from SI Handling Systems, Inc. use a spinning tube in place of a lead screw. Drive wheels connected to a linkage ride on the tube. Adjustment of the linkage causes the drive wheels to pivot relative to the tube axis. When the wheels are perpendicular to the tube, they rotate in place, and the cart is stationary. However, forward motion is achieved when the wheels are positioned at an angle to the tube. It is similar to a lead screw with a variable helix angle. Figure 4 illustrates this feature.

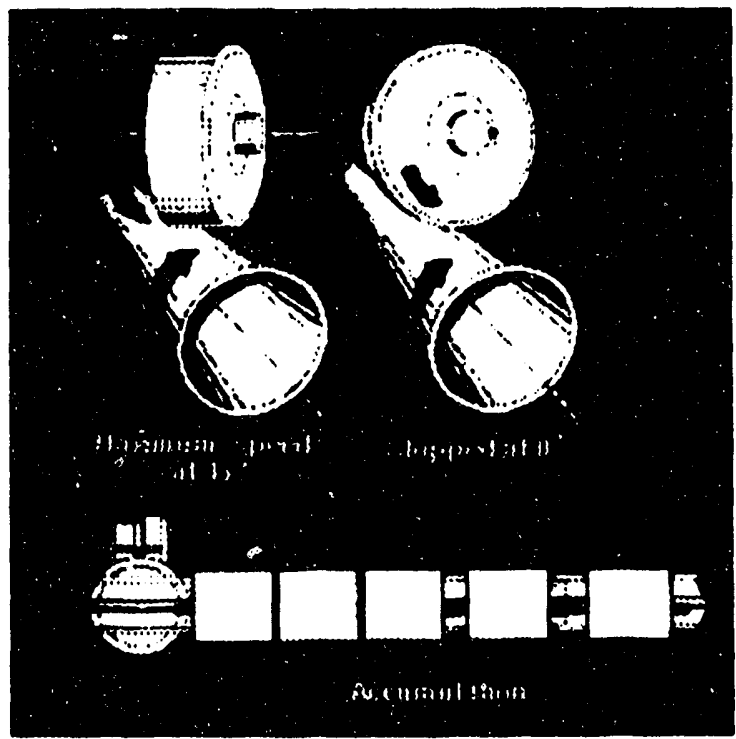

Figure 4

Cartrac® Drive System

Angle of Drive Wheel Determines Speed 


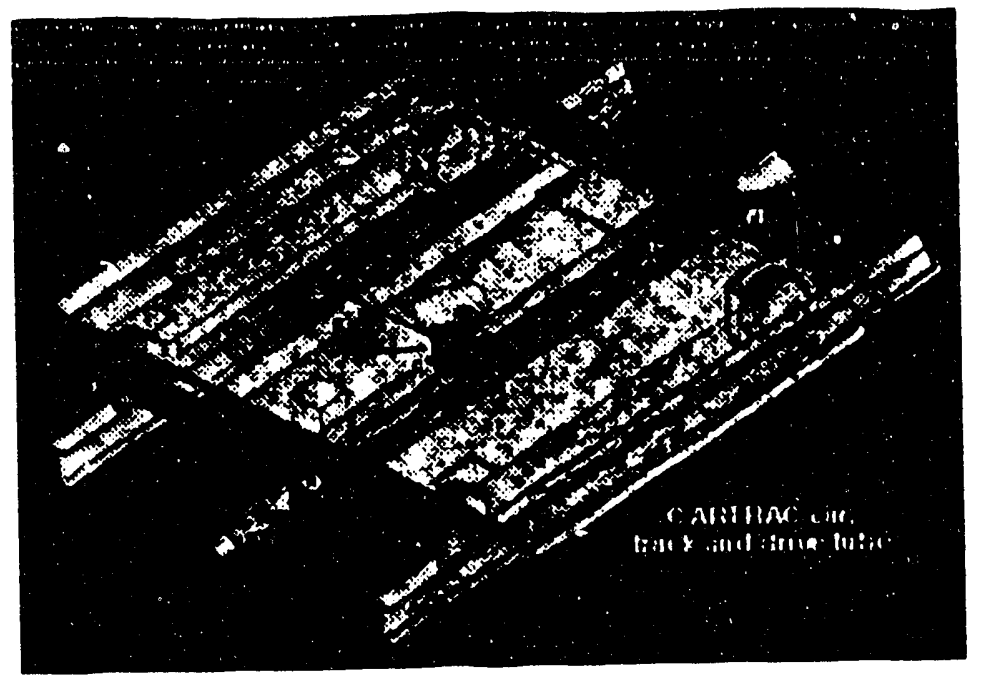

Figure 5

\section{Cartrac ${ }^{\circledR}$ Car, llustrating Cam Follower and Linkage to Control Drive Wheel Angle}

Carts are constructed with a cam follower on the linkage protruding from the front of the cart. A typical cart is shown in Figure 5. Carts also have a cam protruding from their rear. In this manner, the cam follower from a following car is actuated by the cam of a leading car, causing the following car to slow or stop before it collides with the leading car. This creates a self-accumulating system, as shown in the bottom of Figure 4. Cart queuing is accomplished by use of a " $Q$ station" shown in Figure 6.

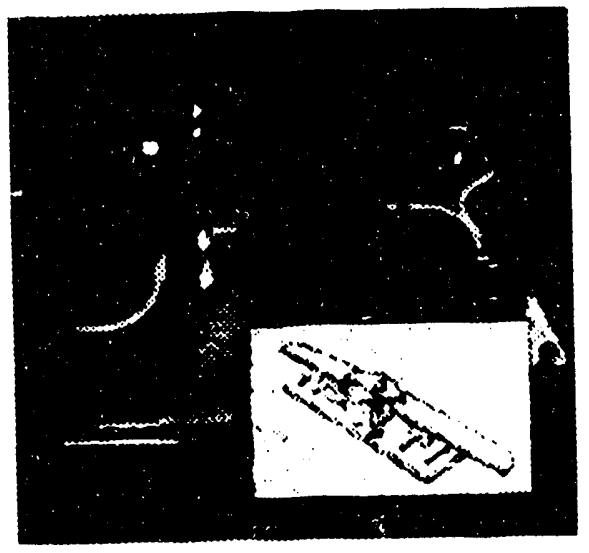

Figure 6

QStation, Illustrating Pneumatically Actuated Queuing Cam 
The Mini-Cartrac may be a good candidate for glovebox service, as the carts are relatively simple, and could be removed to a maintenance area, rather than repaired in place, when maintenance is required. The spinning tube could be engineered to have the drive system external to the glovebox. The only difficulty lies in the method of controlling the cart drive linkage.

The method used by industry is to have pneumatically actuated cams inserted into the path of the cam follower on the linkage (a $Q$ station). This causes the linkage to be actuated, the wheels to rotate perpendicular to the tube, and the cart to slow to a gradual stop. Although the pneumatic cam actuation at the $Q$ station is acceptable to industry, it adds to the maintainability concerns in the glovebox. No applications of a Cartrac in a glovebox were found.

A self-propelled battery powered cart system for glovebox use was developed at Idaho National Engineering Laboratory (INEL) in conjunction with ProgrammaTrak. The application was sample vial transfer between gloveboxes as part of the Laser Isotope Separation initiative, which has since been canceled. Trays containing vials would be moved between gloveboxes by the battery powered carts. A development system still exists at the Test Reactor Area (TRA) at INEL, which was demonstrated for the authors.

The system at TRA was essentially a modified commercial system, whose intended market was silicon chip manufacturing. A sketch of the commercial system is shown in Figure 7. Each cart had two NiCad batteries, a stepper motor, drive wheels, communication module, and photoelectric collision avoidance sensors. Node control communication stations were located at various points around the track. As carts would pass over the communication station, the cars would communicate via infra-red. The use of infra-red enables communications through a transparent window mounted in the duct or glovebox floor. Carts communicate battery charge, battery temperature, and cart ID number. The control system would respond with an instruction to proceed, stop, or start. The control system would also direct the operation of a routing module or transfer station. A typical system configuration is illustrated in Figure 8. 


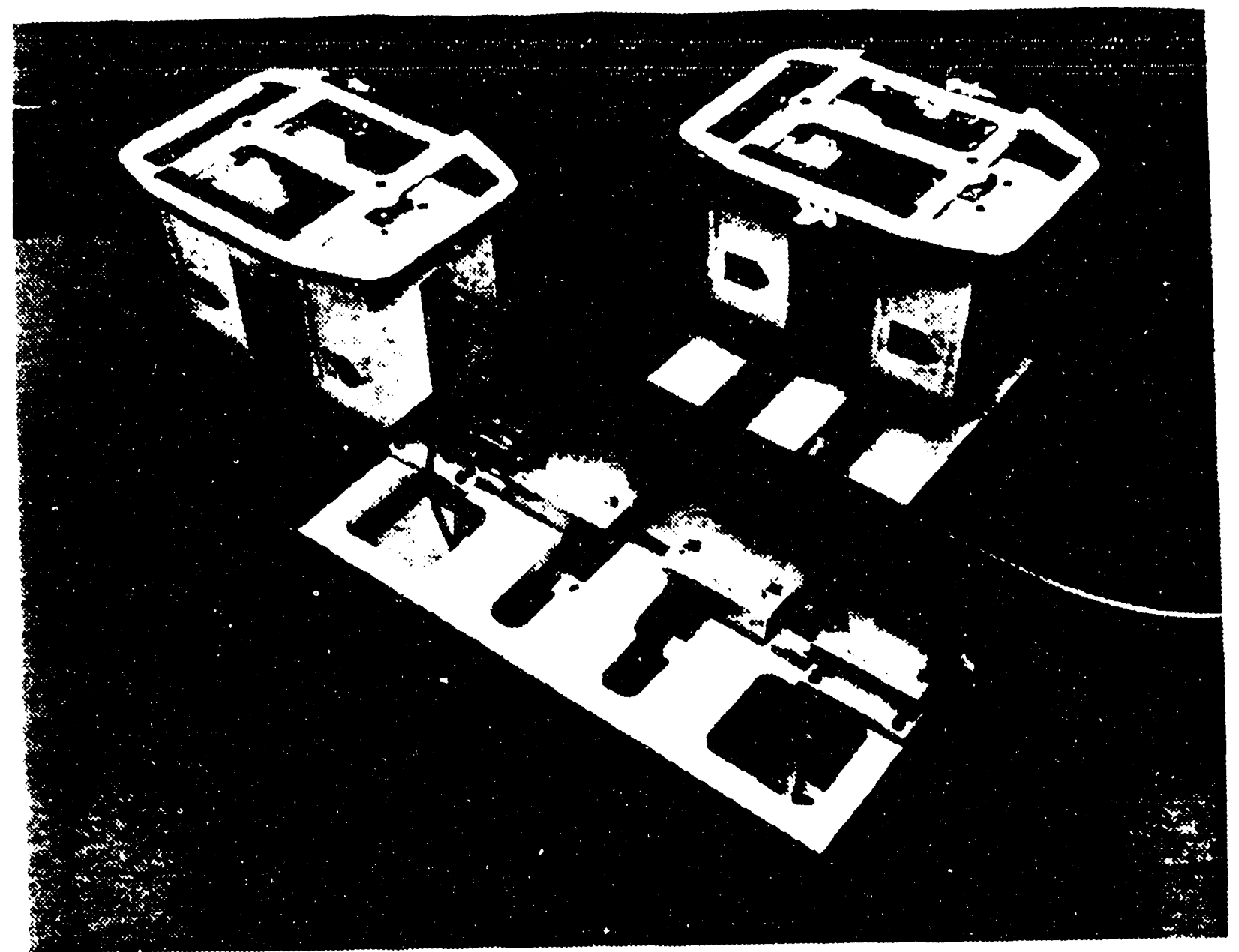

Figure 7

ProgrammaTrak ${ }^{\text {Th }}$ Carts

One Cart on Main Path, Other Cart in Transfer Station

The system is conceptually similar to a railroad train and track operation. A single track is all that is used for most of the system. Switching stations; either routing modules for alternate paths or transfer stations for cart removal; allow versatile routing. However, they both require hardware that significantly increases the system complexity. The method implemented by ProgrammaTrak has the cart stop on a section of track, which is then moved laterally into a workstation, or to an alternate track path. A "replacement" section of track is simultaneously moved into position to fill the gap created by removing the track section with the cart on it. This allows for other traffic to utilize the main loop, instead of having a bottleneck. However, the inherent advantage of a passive track is lost, and maintenance difficulties are increased. 


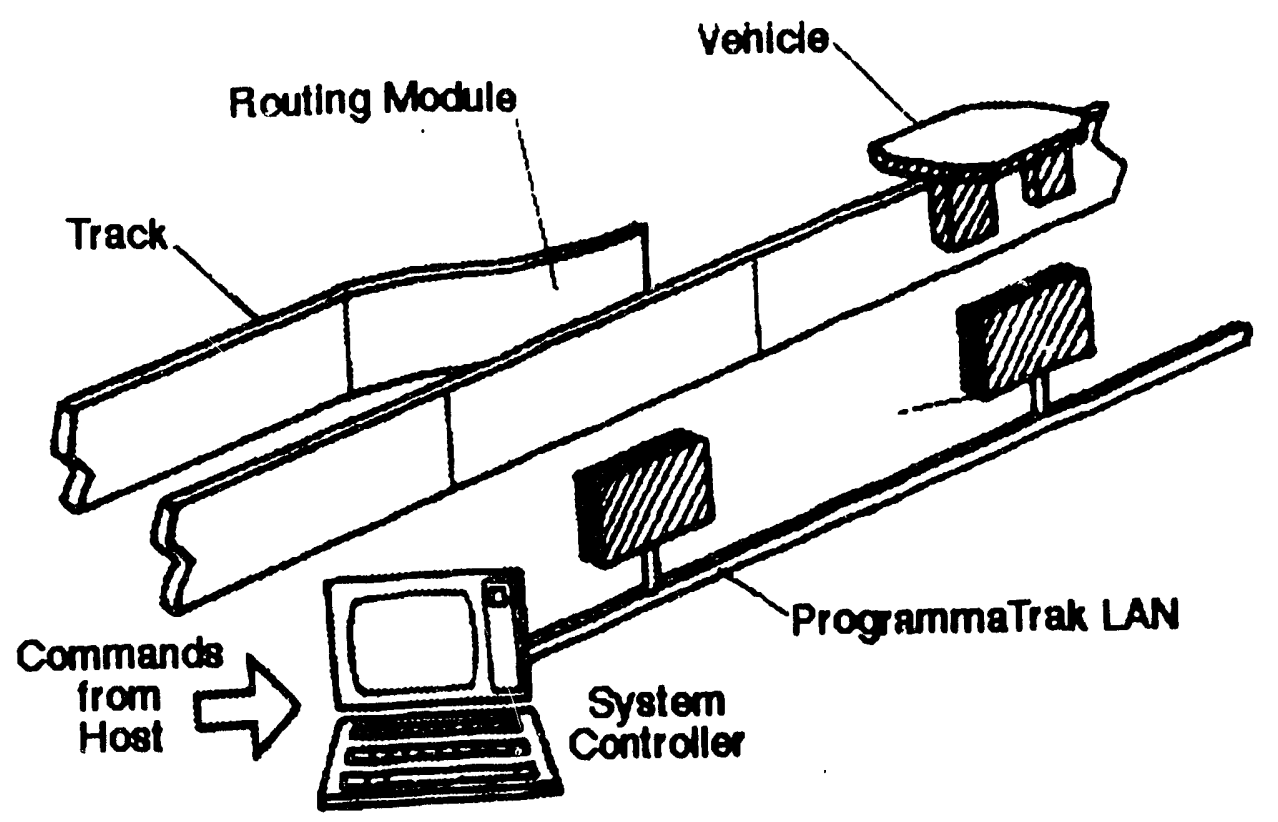

Figure 8

ProgrammaTrak ${ }^{\text {Mi }}$ System Configuration

Modifications for use in gloveboxes consisted of sealing the cart for use in a contamination environment and altering the control structure for incorporation into a material accountability system. Control system diagnostics were also expanded. Due to the prototypic nature of the system at TRA, certain deficiencies were noted which would be improved for a production version. For example, components were not packaged into field replaceable modules. INEL personnel should be consulted if this system is pursued, as they have identified many areas for improvement.

The carts would monitor their battery charge, and recharge automatically when idle at a charging location. One feature added for glovebox use was that failed carts could be retrieved by pushing them along with a second cart. (Collision avoidance sensors that normally prevent cart collisions would have to be bypassed to do this.) The main path that the cart travels on is a passive guide rail, $1 / 4$ " thick by 6 " high. The simplicity of the installed equipment for point to point moves was a desirable feature. However, more complicated equipment is required to create a system that will allow multiple carts to work simultaneously. 
Although the system does offer many advantages, the method of moving a cart into a station requires complex hardware to be installed in the containment duct. It is specifically this type of complex hardware that is objectionable in future facilities. A new method would have to be conceived before this system would be a viable candidate for glovebox use.

\section{Linear Motor Systems}

Linear motors are similar to conventional rotary motors, in that the polyphase current flow in the stator (or primary) produces a moving magnetic field, which generates torque in the rotor (or secondary). However, with a linear motor, the primary is flat, often in sections about four feet long, and a permanent magnet (secondary) is attached to the bottom of a transport cart. Actuation of the motor results in the cart moving along the length of the primary. Nonmagnetic materials can be placed between the primary and secondary while still retaining the desired action of the secondary moving in response to the current flow in the primary. The DOE complex makes use of this to place a non-magnetic ( 300 series stainless steel) barrier between the motor primary (located in a clean area) and the secondary (located in the contamination environment). A diagram of this arrangement is shown in Figure 9.

Linear motors which utilize a permanent magnet secondary are also called linear synchronous motors. Instead of a permanent magnet, the secondary can also be constructed of non-magnetic conductors, sucin as copper bars. For this arrangement to work, the moving field in the primary must induce the current in the secondary. Linear induction motors are constructed in this manner. Linear induction motors are used for higher speed applications, and have not been found in glovebox applications. For this reason, the discussion on linear motors will be limited to linear synchronous motors.

Four linear motor systems were identified in the DOE complex. Three of these were in the Remote Analytical Laboratory (RAL) at INEL. The other was in Building 771 at Rocky Flats. All installations were visited by the authors. 


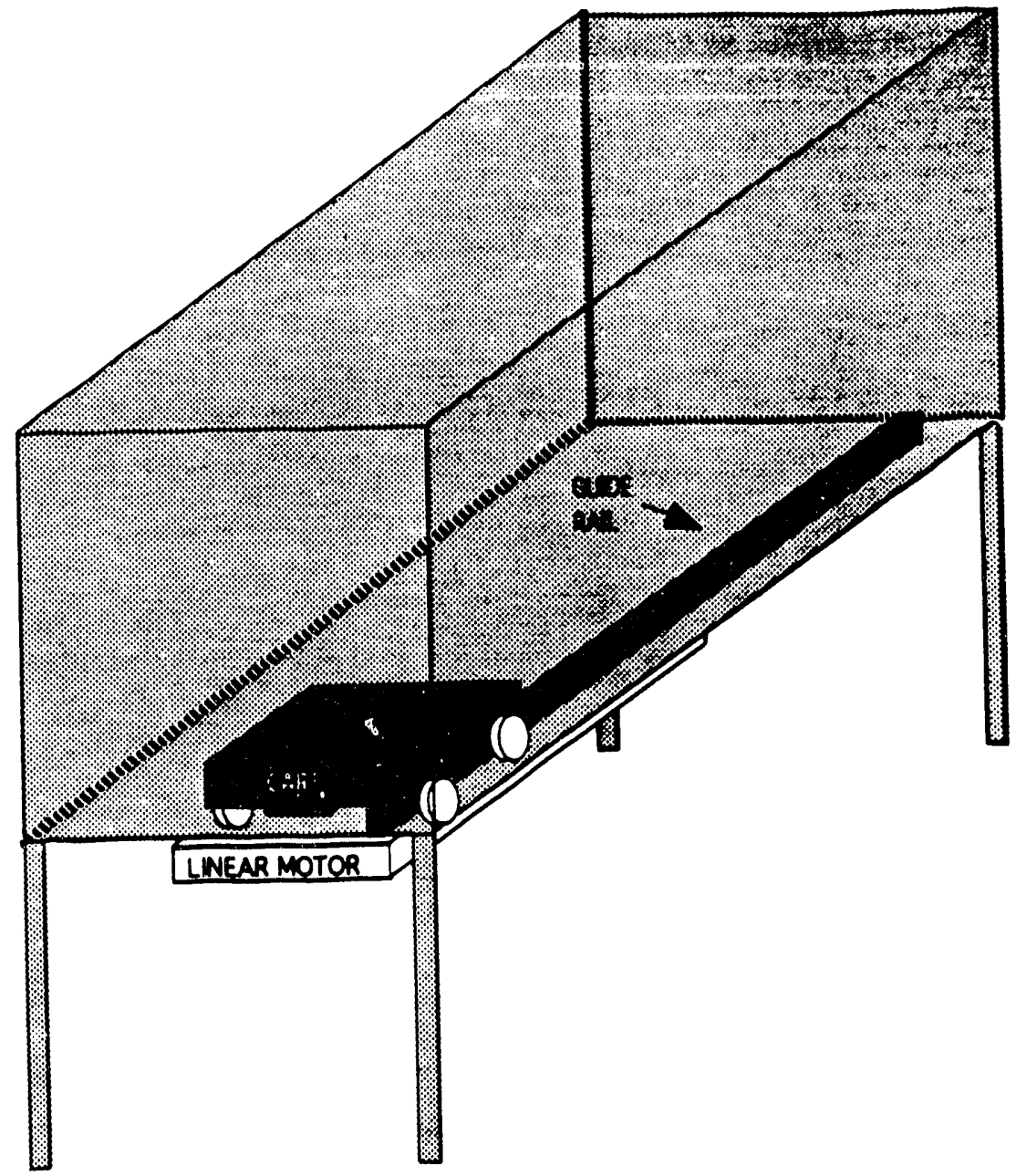

Figure 9

Linear Motor and Cart for Glovebox Use

At INEL, three linear motor systems were installed in a series of analytical cells and hoods in RAL. These presented similar maintenance concerns to glovebox operations, and are considered directly relevant. One of the two systems installed in the cells worked quite well, although some abrupt changes in velocity were noted (jerky operation). The other did not work well due to variations in the cell floor smoothness. The cart would become hung on high spots, resulting in the need for operator intervention. The third linear motor was installed along the back of a line of laboratory hoods. However, it was beyond the operator's reach, and seldom used. The following observations were made: 
- Linear motor primaries were located in a tunnel that only opened to the clean area.

- Operator interface was extremely simple - Pushbuttons were used to send the carts to the various stations.

- Floor flatness is critical (to prevent cart from getting "hung").

- Guides to provide cart axial alignment are required. A raised rail in the cell floor engaged $a$ slot in the wheels on one side of the vehicle to keep it centered. The system behind the laboratory hoods jammed against the tunnel sides frequently. Dimensional tclerances must be considered.

- Cart magnets are fragile and difficult to replace (with manipulators). The attraction of the magnet to the motor primary made placing the cart on the rail difficult.

- Cart wheels were fabricated from cam followers, so that the bearing was integral to the assembly. Wheels could easily be changed with manipulators.

- Trash can fill the small gap required between the cart magnet and the cell floor. The cart will stall if this happens. Thermocouples embedded in each linear motor will shut down the motor when overhearing occurs.

- Small magnets located under the cart activated sensor switches under the cell floor which stopped the cart at the desired station.

- The control system was implemented on an Allen-Bradley PLC2 controller. Allen-Bradley variable speed AC motor controls were used to regulate cart speed. Speed adjustment was accomplished by rotating the appropriate knob in the motor controller.

- INEL did not remember ever needing to replace a motor section.

The "button breakout go-rart" at Rocky Flats (RF) is used to transport reaction vessels (RVs) from induction furnaces to cooling stations. The RVs are quite heavy ( $2 \mathrm{~S}$ lbs.), creating the need for a transport system. The system was not operational during the visit due to restrictions on work at RF. However, one of the stainless steel carts was in a maintenance position (upside down), and could be easily observed. RF operating experience found the cart position sensor system to be unreliable. and they had bypassed it years ago. The cart simply drives as long as the proper button is depressed. The 
rare-earth magnets mounted to the bottom of the cart were visibly damaged. This is attributed to two factors. The first is metal particles accumulating in the vehicle trough, and causing magnet abrasion. The second is dropping the cart when installing it in the trough, due to the high magnetic attraction. Cart magnets could be replaced by removing twelve socket-head cap screws using hand tools and the glovebox gloveports. In-box maintenance was acceptable. The structural welds joining glovebox sections were ground smooth to prevent interference with cart motion.

The trough was used so that the working surface of the cart was flush with the RV pickup and deposit locations. A rail was used to center the cart in the trough. Linear motors were mounted to the bottom of the glovebox, and were readily accessible in the clean area. Motor failure was rare, and the overall system reliability quite high. Speed adjustment was accomplished at the Allen-Bradley control cabinet by adjusting a trim pot on the motor controller.

Both INEL and RF had similar experience with linear motors. Flatness and cleanliness of the vehicle operating surface improved system performance. Motor primaries were highly reliable, however the rare-earth permanent magnets were brittle and easily damaged. Epoxy coating of the magnets has been proposed, but not demonstrated by either site.

\section{Pneumatic Systems}

Pneumatic systems for sample transport were noted both at INEL and Rocky Flats. Although sample transport is not the focus of this report, the systems are noted here for future reference. INEL utilized pressurized systems, while Rocky Flats was developing a vacuum based system.

INEL uses a pressurized pneumatic sample transfer system between the Idaho Chemical Processing Plant (ICPP) and the RAL. Primary containment is achieved by placing the liquid sample in a transport vial. Secondary containment is provided by the welded stainless steel transfer tubing. Contamination of the pneumatic system has reportedly occurred at INEL. A pressurized system such as this appears to be unacceptable in new facilities due to the potential for contamination spread. 
Rocky Flats demonstrated the vacuum based pneumatic transfer systems. The systems were developed in the laboratory for two sample vial transfer applications at RF, neither of which are presently scheduled for installation. Use of vacuum instead of pressure eliminates the possibility of glovebox pressurization, and mitigates the chance for contamination migratiou. Double containment of the transfer lines is provided, by using a tube within a tube. The use of polyethylene tubing allows for smooth bends, no weld joints, and easy installation. One particularly tight turn had caused the tube cross section to assume an oval shape - external supports had to be added to allow it to return to a circular cross section. A computer model has been developed by Rocky Flats to predict system transit times. The prediction allows the control system to flag the user if a sample is "late" in arriving, thus allowing for corrective action. The system appears to be superior to the pressurized pneumatic system at Idaho. Much of hardware was offthe-shelf.

A "Y" transfer was also used on some applications. The flexible polyethylene allowed lateral movement such that the single inlet tube could be easily aligned with either of two output tubes. This was used to accomplish selective routing. Sample vials from this system were being automatically stored by a robot in a sample storage system. Redundant robots, storage systems, and pneumatic transfer systems were used to achieve high system reliability.

The chief advantage of pneumatic transfer systems (either pressure or vacuum based) for movement of sample vials is that the system eliminates the need to bag samples in and out of the boxes. Polyethylene tubing is in use at SRTC in one of the irradiation facilities. Operating experience suggests that the polyethylene works quite well in this application, and should be considered for sample vial transfers in future facilities.

Pneumatic transfer systems, especially with vacuum as the motive force, appear to be quite useful for small sample transfer. The use of polyethylene tubing can reduce installation cost, and provide for flexible routing. Use of welded stainless steel systems should require evaluation of polyethylene as an alternative. 


\section{CONCLUSION}

Conveyor based systems observed at Hanford should be used only after other means have been considered and rejected. The maintenance difficulties appear to override any perceived advantage to these systems. However, specific applications of the Dorner conveyors may be appropriate when maintenance frequency is not excessive.

The self-propelled battery powered cart appeared to be quite promising, however the mechanism for lateral movement will require significant development. Cart redesign to accommodate maintenance in a glovebox would also be desirable.

Linear motors have been successfully employed in several straight line applications in gloveboxes and hot cells at DOE sites. No instances of multiple carts on a linear motor based system were observed. No right angle turns or other branching schemes were observed. Operating experience with linear motors indicated that the primaries are quite reliable, and easy to access when repair is needed. The simplicity of the cart with the secondary mounted on it is typically governed by the wheel assembly. No maintenance difficulties were reported with the carts.

It is recommended that investigation into linear motor technology with leading vendors in the field be pursued. A development plan to demonstrate control integration, right-angle turns, and the reliability, availability, and maintainability of linear motors for all aspects of glovebox transport should be created, and funding to execute the plan also pursued. The benefits of a highly maintainable system, including reduced facility operating costs and reduced radiation exposure to maintenance and operating personnel, should justify initiation of development activities. 


\section{APPENDIX}

Glovebox Transport Technologies

Observed in the DOE Complex, By Site

\begin{tabular}{|l|l|l|l|l|}
\cline { 2 - 5 } \multicolumn{1}{c|}{} & Rocky Flats & INEL & $\begin{array}{l}\text { Hanford } \\
\text { (FMEF) }\end{array}$ & $\begin{array}{l}\text { Savannah } \\
\text { River }\end{array}$ \\
\hline Conveyors & & $\begin{array}{l}\text { Dorner Belt } \\
\text { Conveyor } \\
\text { Shuttleworth } \\
\text { Slip-Torque }\end{array}$ & \\
\hline $\begin{array}{l}\text { Cart } \\
\text { Systems }\end{array}$ & & $\begin{array}{l}\text { Modified } \\
\text { Programma- } \\
\text { Trak }\end{array}$ & & $\begin{array}{l}\text { Manual - } \\
\text { Custom Built }\end{array}$ \\
\hline $\begin{array}{l}\text { Linear } \\
\text { Motors }\end{array}$ & Magnetics & $\begin{array}{l}\text { Northern } \\
\text { Magnetics }\end{array}$ & & \\
\hline Pneumatics & Vacuum Based & $\begin{array}{l}\text { Pressure } \\
\text { Based }\end{array}$ & & \\
& & & & \\
\hline
\end{tabular}




\section{REFERENCES}

1. T. H. Allegri, Sr. Materials Handling - Principles and Practice. Van Nostrand Reinhold Cornpany, Inc., New York (1984).

2. J. R. Immer. Materials Handling. McGraw-Hill Book Company, Inc., New York (1953).

3. R. M. Eastman. Materials Handling., Marcel Drekker, Inc., New York (1987).

4. E. R. Sims. Material Handling in Manufacturing Operations. Lecture Notes (1987).

5. Plutonium Processing Automation Review Team Final Report. USDOE Publication DOE/DP-9020854, Washington, DC (1988).

6. P. J. Eicker (Technical Editor). Robotics and Automation Technologies for Weapons Complex Applications. USDOE Publication SAND91-1573, Sandia National Laboratories, Albuquerque, NM (1991).

7. D. R. Doman. Design Guides for Radioactive Material Handling Facilities and Equipment. American Nuclear Society, La Grange Park, II (1988). 
Ms. W. F. Perrin, Technical Information Officer

U. S. Department of Energy

Savannah Rtver Operations Office

Alken, SC 29801

Dear Ms. Perrin:

\title{
REQUEST FOR APPROVAL TO RELEASE SCIENTIFIC/TECHNICAL INFORMATION
}

The attached document is submitted for classification and technical approvals for the purpose of external release. Please complete Part II of this letter and return the letter to the undersigned by $02 / 03 / 93$. Patent clearance, if necessary, is requested and recelved via direct communications between this office and the DOE-SR Patent Counsel. The document has been reviewed for classification by a WSRC classification staff member and has been determined to be Unclassified

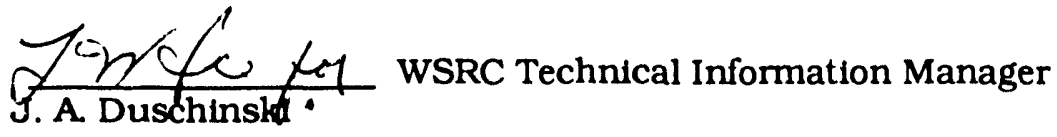

\section{DETAILS OF REQUEST FOR RELEASE}

Document Number: WSRC-RP-92-1337

Pub Deadline: $N \hat{\imath}$

Author's Name: G. D. Teese

Location: 723-9A

Document TItle: MATERIAL HANDLING SYSTEMS FOR USE IN GLOVEBOX LINES

\author{
- A SURVEY OF DEPARTMENT OF ENERGY FACILITY \\ EXPERIENCE (U) \\ Manager's Name: J. P. Veldman \\ Department: Equipment Engineering
}

A technical deliverable being deposited to OSTI for unlimited distribution to the general public. Technical questions pertaining to the contents of this document should be addressed to the author(s) or the Manager. Questions concerning the processing of this document should be addressed to the WSRC Technical Information Manager, 5-3992 or 5-2099/5-3384.

II. DOE-SR ACTION

Q Approved

$\square$ Approved Upon Completion of Changes Approved with Remarks
Date Recelved by TIO 12-18-92

Not Approved

Revise and Resubmit to DOE-SR

Remarks

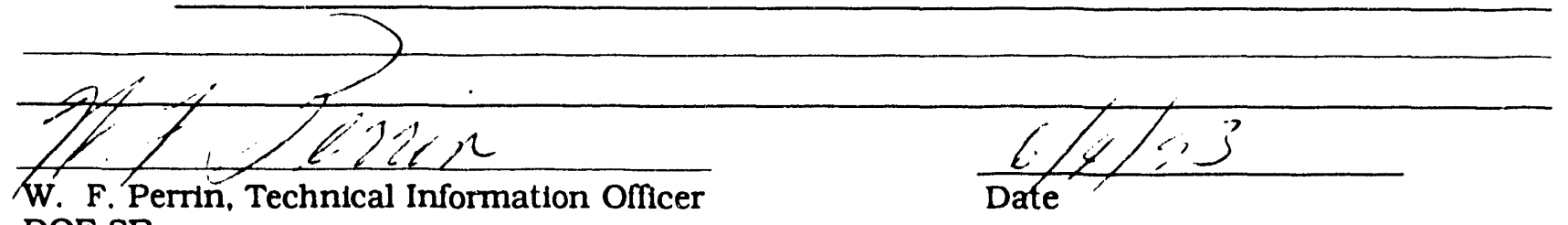
DOE-SR

$\mathrm{JAD} / \mathrm{mag}$ 



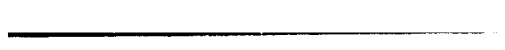

